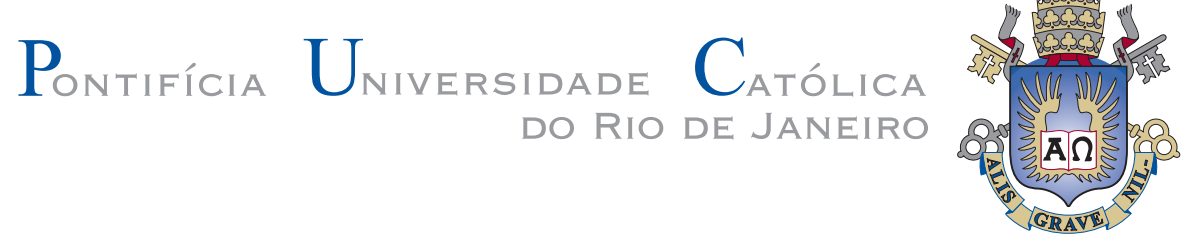

Fabrício Carlos Pinheiro de Oliveira

\title{
Petroleum Supply Chain Management under Uncertainty: Models and Algorithms
}

TESE DE DOUTORADO

Thesis presented to the Programa de Pós-Graduação em Engenharia de Produção of the Departamento de Engenharia Industrial , PUC-Rio as partial fulfillment of the requirements for the degree of Doutor em Engenharia de Produção

Advisor: Prof. Silvio Hamacher

Rio de Janeiro

September 2012 


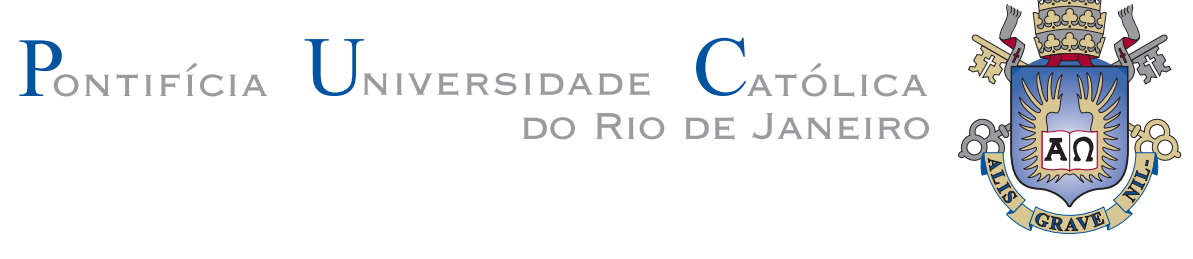

Fabrício Carlos Pinheiro de Oliveira

Petroleum Supply Chain Management under Uncertainty: Models and Algorithms

Thesis presented to the Programa de Pós-Graduação em Engenharia de Produção of the Departamento deEngenharia Industrial do Centro Técnico Científico da PUC-Rio, as partial fulfillment of the requirements for the degree of Doutor.

Prof. Silvio Hamacher

Advisor

Departmento de Engenharia Industrial - PUC-Rio

Prof. Abilio Lucena

Departmento de Administração - UFRJ

Prof. Fernanda Raupp

Departmento de Engenharia Industrial - PUC-Rio

Prof. Ignacio E. Grossmann

Department of Chemical Engineering - Carnegie Mellon

Prof. Virgílio Ferreira Filho

Universidade Federal do Rio de Janeiro - COPPE/UFRJ

Prof. José Eugênio Leal

Coordinator of the Centro Técnico Científico - PUC-Rio

Rio de Janeiro — September 11, 2012 
All rights reserved.

Fabrício Carlos Pinheiro de Oliveira

Fabrício Oliveira graduated from PUC-Rio in Industrial Engineering. Since 2007, he has worked at the Center of Excellence in Optimization Solutions (NExO/PUC-Rio) where he has participated and coordinated research projects in Petroleum Supply Chain planning.

Bibliographic data

Oliveira, Fabrício Carlos Pinheiro de

Petroleum Supply Chain Management under Uncertainty: Models and Algorithms / Fabrício Carlos Pinheiro de Oliveira; adviser: Silvio Hamacher. - Rio de Janeiro : PUC-Rio, Departmento de Engenharia Industrial, 2012.

97 f.: il. (color) ; $30 \mathrm{~cm}$

Tese (Doutorado) - Pontifícia Universidade Católica do Rio de Janeiro, Departamento de Engenharia Industrial, 2012.

Inclui bibliografia.

1. Engenharia Industrial - Teses. 2. Gestão da cadeia de suprimentos de petróleo. 3. Planejamento estratégico. 4. Otimização sob incerteza. 5. Programação estocástica. 6. Estratégias de decomposi cão. I. Hamacher, Silvio. II. Pontifícia Universidade Católica do Rio de Janeiro. Departamento de Engenharia Industrial. III. Título. 
To my wife Jeniffer, my father Julio, and my mother Francisca. 


\section{Acknowledgments}

I would like to express my gratitude to my adviser, Prof. Silvio Hamacher. He was, and still is, one of the greatest examples in my life. I am eternally grateful for all the doors that he have opened for me, his continuous support, and trust. I hope that I can still count with his friendship and his guidance for the years to come.

It was an honor for me having the opportunity to work with Prof. Ignacio Grossmann at Carnegie Mellon University. It was an incredible experience to be able to learn so many new things with him and his group. My sincere thanks goes to him for his support and dedication to me during my stay.

I would like to thank Prof. Alexandre Street and Prof. Luiz Felipe Scavarda from PUC-Rio for their support, friendship, and example of being a good teacher.

I also want to thank my friends for listening to my considerations and the support during my PhD. I had an incredible time during these years and it was mostly because of you.

This work would have never been possible without the unconditional love and support of my family, especially from my beloved wife Jeniffer. I know it was though to be away, but I don't think I would have made through without her support. My gratitude to her is beyond what words can express.

At last, I would like to acknowledge the financial support from the $\mathrm{CNPq}$ grant throughout these years, especially when I was abroad during my internship at Carnegie Mellon University. 


\section{Abstract}

Oliveira, Fabrício Carlos Pinheiro de; Hamacher, Silvio(adviser). Petroleum Supply Chain Management under Uncertainty: Models and Algorithms. Rio de Janeiro, 2012. 97p. Tese de Doutorado - Departamento de Engenharia Industrial, Pontifícia Universidade Católica do Rio de Janeiro.

In this thesis we investigate the investment planning problem for the petroleum supply chain under demand uncertainty. We formulate and solve a two-stage stochastic programming model that seeks to accurately represent the particular features that are inherent to the investment planning for the petroleum logistics infrastructure.

The incorporation of uncertainty in this case inevitably increases the complexity of the problem, which becomes quickly intractable as the number of scenarios grows. We circumvent this drawback by relying on Sample Average Approximation (SAA) to control the number of scenarios required to reach a prespecified level of tolerance regarding solution quality. We also focus on efficiently solving the stochastic programming problem, exploiting its particular structure by means of a scenario-wise decomposition. Following this idea, we propose two novel approaches that focus on decomposing the problem in a way that it could be efficiently solved.

The first algorithm is based on stochastic Benders decomposition, which we further improve by using new acceleration techniques proposed in this study. The second is a novel algorithm based on Lagrangean decomposition that was designed to deal with the case where we have integer variables in the second-stage problem. The novel feature in this algorithm is related with the hybrid strategy for updating the Lagrange multipliers, which combines subgradient, cutting-planes and trust region ideas. In both cases, we have assessed the proposed approaches considering a large-scale realworld instances of the problem. Results suggests that they attain superior performance.

\section{Keywords}

Petroleum supply chain management. Strategic planning. Optimization under uncertainty. Stochastic programming. Decomposition strategy. 


\section{Resumo}

Oliveira, Fabrício Carlos Pinheiro de; Hamacher, Silvio(orientador).

Gestão da cadeia de petróleo sob incerteza: modelos e algoritmos. Rio de Janeiro, 2012. 97p. Tese de Doutorado Departamento de Engenharia Industrial, Pontifícia Universidade Católica do Rio de Janeiro.

Nesta tese é abordado o problema de planejamento de investimentos para a cadeia de fornecimento de petróleo sob incerteza. Neste contexto, um modelo de programação estocástica de dois estágios é formulado e resolvido. Tal modelo busca representar com precisão as características particulares que são inerentes ao planejamento de investimentos para a infra-estrutura logística de petróleo.

A incorporação da incerteza neste contexto inevitavelmente aumenta a complexidade do problema, o qual se torna rapidamente intratável conforme cresce o número de cenários. Tal dificuldade é contornada baseando-se na aproximação por média amostral (AMA) para controlar o número de cenários necessários para atingir um nível pré-especificado de tolerância em relação à qualidade da solução. Além disso, é considerado o desenvolvimento de técnicas que resolvam de maneira eficiente o problema, explorando sua estrutura especial, através de decomposição por cenários. Seguindo esta ideia, propõe-se duas novas abordagens para decompor o problema de forma que o mesmo possa ser eficientemente resolvido.

O primeiro algoritmo é baseado na decomposição estocástica de Benders, a qual é aprimorada usando-se novas técnicas de aceleração propostas. O segundo consiste de um novo algoritmo baseado em decomposição Lagrangeana que foi projetado para lidar com o caso onde temos variáveis inteiras no problema de segundo estágio. A característica inovadora desse algoritmo está relacionada com a estratégia híbrida utilizada para atualizar os multiplicadores de Lagrange, combinando subgradientes, planos de cortes e regiões de confiança. Em ambos os casos as abordagens propostas foram avaliadas considerando um exemplo de grande escala do mundo real e os resultados sugerem que os mesmos apresentam desempenho superior quando comparados com outras técnicas disponíveis na literatura.

\section{Palavras-chave}

Gestão da cadeia de suprimentos de petróleo. Planejamento estratégico. Otimização sob incerteza. Programação estocástica. Estratégias de decomposi cão. 


\section{Contents}

1 Introduction $\quad 12$

1.1 Objectives 13

1.2 Thesis Organization 14

2 Problem Statement $\quad 15$

2.1 Problem Description $\quad 15$

2.2 Mathematical Model 18

Nomenclature 18

Model Formulation $\quad 21$

First-stage problem $\quad 21$

Second-stage problems $\quad 22$

3 Dealing with Demand Uncertainty using Sample Average Approximation $\quad 26$

3.1 Sample Average Approximation 27

Lower bound approximation 28

Upper bound approximation $\quad 29$

Estimating the gap $\quad 30$

3.2 Scenario generation using SAA 31

3.3 Case Study 33

Case description 33

Results 37

3.4 Conclusions 41

4 Scenario decomposition framework for continuous second-stage problem: stochastic Benders decomposition $\quad 42$

4.1 Mathematical Model 44

Nomenclature $\quad 44$

Model Formulation $\quad 45$

4.2 Stochastic Benders Decomposition 46

4.3 Accelerating Benders Decomposition 49

Multi cut framework $\quad 50$

Generating stronger cuts $\quad 50$

Additional acceleration ideas $\quad 54$

Upper bound improving 54

Trust-region $\quad 55$

Algorithm statement $\quad 56$

4.4 Numerical Experiments $\quad 57$

4.5 Conclusions 60 
5 Scenario decomposition framework for mixed-integer second-stage problem: stochastic Lagrangean decomposition

62

5.1 Mathematical Model 63

Nomenclature 63

Model Formulation 64

5.2 Solution Algorithm 65

Lagrangean Decomposition Approach $\quad 65$

Proposed strategy for solving the Lagrangean Dual 68

Upper bounding procedure $\quad 70$

Multiplier updating procedure 71

Algorithm statement 73

$\begin{array}{lll}5.3 & \text { Risk Management } & 74\end{array}$

$\begin{array}{lll}5.4 & \text { Numerical results } & 76\end{array}$

Example $1 \quad 76$

Example 2 81

5.5 Conclusions $\quad 85$

6 Conclusions $\quad 86$

$\begin{array}{lll}6.1 & \text { Thesis Contributions } & 87\end{array}$

6.2 Future Perspectives $\quad 89$

$\begin{array}{lr}\text { Bibliography } & 91\end{array}$ 


\section{List of Figures}

2.1 Example of a multi-period network investment planning $\quad 15$

$\begin{array}{lll}2.2 & \text { Piecewise linear representation of nonlinear demurrage cost } & 17\end{array}$

$\begin{array}{lll}3.1 & \text { Case study distribution network } & 34\end{array}$

$\begin{array}{lll}3.2 & \text { Case study demand levels } & 36\end{array}$

$\begin{array}{lll}3.3 & \text { Example of demand scenarios } & 37\end{array}$

4.1 Schematic representation of the proposed stochastic Benders decomposition 49

$\begin{array}{lll}4.2 & \text { Geometric illustration of cut strength } & 51\end{array}$

5.1 Schematic representation of the proposed Lagrangean decomposition 69

$\begin{array}{lll}5.2 & \text { Network structure of example } 1 & 77\end{array}$

5.3 Convergence Profile: Subgradient algorithm and sequential formulation 80

5.4 Convergence Profile: Proposed algorithm and sequential formulation $\quad 80$

5.5 Convergence Profile: Subgradient algorithm and asymmetric formulation 81

5.6 Convergence Profile: Proposed algorithm and different algorithms 81

5.7 Multi-scale approximation representation $\quad 82$

5.8 Cost distribution for 200 scenarios 83

5.9 Cost distribution for 200 scenarios after risk management 84

5.10 Cost distribution comparison 85 


\section{List of Tables}

2.1 Model Notation: Sets and subsets 19

2.2 Model Notation: Parameters 20

2.3 Model Notation: Variables 21

3.1 Seaworthiness between locations 35

$\begin{array}{lll}3.2 & \text { Investment portfolio for locations } & 35\end{array}$

3.3 Summary of model sizes 38

3.4 Experiment results: statistical limits (lower and upper) 39

3.5 Experiment results: estimative of the optimality gap 39

3.6 Investment profiles of solution 3 for $N=20$, solution 3 for $N=30$ and solution 2 for $N=40 \quad 40$

4.1 Model Notation $\quad 45$

4.2 Summary of CPU times(s) - experiment $1 \quad 59$

4.3 Summary of CPU times(s) - experiment $2 \quad 60$

5.1 Model Additional Notation 64

$\begin{array}{lll}5.2 & \text { Example } 1 \text { Capacity expansion decisions } & 78\end{array}$

$\begin{array}{lll}5.3 & \text { Example } 1 \text { Network design decisions } & 78\end{array}$

$\begin{array}{lll}5.4 & \text { Summary of CPU times(s) } & 78\end{array}$

5.5 Deterministic Equivalent Sizes $\quad 82$

5.6 Summary of CPU times(s) 82 
To choose doubt as a philosophy of life is akin to choosing immobility as a means of transportation.

Yann Martel, Life of Pi. 